DOI 10.31651/2524-2660-2020-4-90-94

ORCID 0000-0002-0656-2413

DANYLYUK Serhiy,

Doctor in Pedagogy, Professor,

Chair of Pedagogical Sciences, Educational and Socio-Cultural Management Department,

Bohdan Khmelnytsky National University at Cherkasy

e-mail: sergey.danilyuk75@gmail.com

UDC 378.091.12: 364-051(045)

\title{
THE ROLE OF INTERCULTURAL COMMUNICATION IN THE PROCESS OF TEACHING FOREIGN LANGUAGES TO FUTURE MANAGERS OF SOCIO-CULTURAL ACTIVITIES AT THE PRESENT STAGE
}

The need to review goals, objectives and teaching methods in the process of teaching foreign lanquages in Ukraine in connection with the rapid entry of Ukraine into the world community, which, in its turn, leads to changes in both general methodology and specific methods, and techniques in the theory and practice of teaching foreign languages is discussed in the paper.

It is noted that the main purpose of learning a foreign lanquage is the formation of a linquistic personalitu who is readu for real, productive communication with representatives of other cultures at different levels and in different spheres of life. At the forefront is the need for verbal support for intercultural communication.

Emphasis is placed on the fact that an integrative approach to foreign lanquage teaching is especially important in the context of intercultural dialoque, which assumes that the interaction of different worldviews presented by communicators includes their logics, thinking, values and is not blocked but stimulated by mutual understanding, tolerance, positive attitude.

It is emphasized that relations are intercultural if their participants do not resort to their own traditions, customs, ideas and ways of behavior, but get acquainted with other people's rules and norms of everyday communication. Intercultural communication requires that the sender and recipient of the message belong to different cultures. It also requires participants in communication to be aware of each other's cultural differences. In essence, intercultural communication is always interpersonal communication in a special context, when one participant discovers the cultural difference of another.

It is also said that successful intercultural communication involves, in addition to foreign language proficiency, the ability to adequately interpret the communicative behavior of a representative of a foreign society, as well as the willingness of participants to perceive other forms of communicative behavior, understanding its differences and variation from culture to culture. The strategy of convergence of non-cultural knowledae is aimed at preventing not only semantic but also cultural failures in communication.

Keywords: intercultural communication; teaching foreign lanquages; managers of socio-cultural activities; a linquistic personality; participants in communication; cultural differences; interpersonal communication; communicative behavior.

Formulation of the problem. In the process of teaching foreign languages in Ukraine there is currently a period of revision of the goals, objectives and methods of teaching in connection with the rapid entry of Ukraine into the world community, which, in its turn, leads to a change in both the general methodology and specific methods and techniques in theory and practice of teaching foreign languages.

Analysis of recent research and publications. Problems of intercultural communication have been studied by many domestic and foreign scholars, including N. Aliyev, M. Barrett, O. Hryva, L. Kuznetsova, A. Polupan, O. Konstantynova, S. Gogilchyna, Ye. Vereshchagyna, V. Kostomarov, V. Furmanov, G. Tomakhin, Z. Hasanov, T. Petrov, I. Kalisetska, I. Kryazh, N. Markov, etc.

The purpose of the proposed study is to describe the the role of intercultural communication in the process of foreign languages teaching to future managers of socio-cultural activities at the present stage.

Presenting main material. In modern society, it is the practical knowledge of a foreign language that is the main goal of not only linguistic, but also any education, since there is a growing need for specialists in various fields of knowledge, practically speaking one or several foreign languages. Therefore, the main goal of teaching a foreign language is the formation of a linguistic personality, who is ready for real, productive communication with representatives of other cultures at various levels and in various spheres of life. The foreground is the need for verbal support for intercultural communication (establishing personal contacts, conducting telephone conversations, exchanging correspondence, holding presentations, meetings, negotiations, participating in conferences and seminars). Language as the main exponent of the identity of culture is also the main mediator in the intercultural communication process [1].

Thus, a foreign language speaker must not only correctly formulate thoughts in a foreign language, but also comply with the cultural norms adopted by the speakers of the target language. Mastering the language, the student must penetrate into a different system of values and life guidelines and integrate it into his/her own picture of the world. 
Depending on how adequately people understand the values of their culture and compare them with the values of the cultures of other peoples, the well-being of a given people is also determined.

An integrative approach to teaching foreign languages in the context of a dialogue of cultures has acquired particular importance in this regard. The dialogue of cultures assumes that the interaction of different pictures of the world presented by communicants includes their logics, thinking, value meanings and is not blocked, but stimulated through mutual understanding, tolerance, and positive attitude.

Numerous studies of the issues of interaction of cultures indicate that the content and results of diverse intercultural contacts largely depend on the ability of their participants to understand each other and reach agreement, which is mainly determined by the ethnic culture of each of the interacting parties, the psychology of peoples, values, dominating in a particular culture. In cultural anthropology, these relationships between different cultures are called "intercultural communication", which means the exchange between two or more cultures and the products of their activities, carried out in various forms [2]. This exchange can take place both in politics and in the interpersonal communication of people in everyday life, family, informal contacts.

Relationships are intercultural if their participants do not use their own traditions, customs, ideas and behaviors, but get acquainted with other people's rules and norms of everyday communication. For intercultural communication, it is necessary for the sender and recipient of the message to belong to different cultures. It also requires the communication participants to understand each other's cultural differences. In its essence, intercultural communication is always interpersonal communication in a special context, when one participant discovers the cultural difference of the other [3].

It is known that communication occurs at three levels: communicative, interactive and perceptual. The communicative level is contact through the language and cultural traditions characteristic of a particular community of people. The result of this level of interaction is mutual understanding between people. The interactive level is communication that takes into account the personal characteristics of people. It leads to certain relationships between people. The perceptual level provides an opportunity for mutual knowledge and rapprochement of people on this rational basis. It is a process of partners' perception of each other, determining the context of the meeting. Perceptual skills are manifested in the ability to manage their perception, "read" the mood of partners by verbal and non-verbal characteristics, understand the psychological effect of perception and take them into account to reduce its distortion [2].

A necessary condition for communicative interaction is communicative competence, which is understood as the possession of several types of general knowledge shared by communicants $[1 ; 4 ; 5]$. They are formed, firstly, from the knowledge of the symbolic system proper, within the framework of which communication takes place, and, secondly, from the knowledge about the structure of the external world. Knowledge about the external world consists of the individual's personal experience, basic, fundamental knowledge about the world that all people have, and all other knowledge that people possess due to their belonging to various national, ethnic, social, religious, professional and other groups.

Taking into account the named factors of the communicative process, the Council of Europe back in 1986 identified six components in the concept of "communicative competence" that must be taken into account in the learning process:

- linguistic competence as "the ability to reproduce and interpret meaningful statements, built in accordance with the rules of the language and expressing their generally accepted meaning";

- socio-linguistic competence as "the selection of such methods in which the choice of linguistic forms is determined by such conditions, as the environment, the relationship between communication partners, communicative intention, etc.";

- discourse competence as "the ability to use acquired strategies in the construction and interpretation of the text";

- strategic competence as "the ability to use communication strategies of various kinds to overcome difficulties in communication";

- socio-cultural competence as "an essential ability to use the language correctly and appropriately, as well as a condition for expanding the student's communicative horizon beyond that which corresponds to his / her linguistic community";

- social competence which "presupposes the presence of desire and ability to interact with others and differs from other components in that it is less language-oriented and more concerned with the personality of the student".

Thus, successful intercultural communication presupposes, along with knowledge of 
a foreign language, the ability to adequately interpret the communicative behavior of a representative of a different society, as well as the readiness of communication participants to perceive another form of communicative behavior, to understand its differences and variation from culture to culture. The strategy of convergence of foreign culture knowledge is aimed at preventing not only semantic, but also cultural failures in communication. The main problem here is the problem of understanding. When solving it, it should be remembered that language is only a tool for conveying forms of speech behavior, it only creates an environment for intercultural communication. Understanding in intercultural communication is a complex process of interpretation, which depends on a complex of both linguistic and non-linguistic factors [6]. To achieve understanding in intercultural communication, its participants must not only master the grammar and vocabulary of a particular language, but also know the cultural component of the meaning of a word, the realities of a foreign culture.

The point is that the real use of words, real speech reproduction is largely determined by the knowledge of the social and cultural life of the speech community speaking this language. Language does not exist outside of culture, that is, outside of the socially inherited set of practical skills and ideas that characterize our way of life. Since linguistic structures are based on socio-cultural structures, then for the active use of language as a means of communication, it is necessary to know the world of the language being studied as deeply as possible [7].

Without knowing the world of the language being studied, it is impossible to master the language as a means of communication. It can only be mastered as a way of storing and transmitting information, as a "dead" language, devoid of life-giving soil - the culture of the carrier. This, by the way, explains the failures with artificial languages, which have not become widespread and are doomed to die.

That is why the study of a foreign language presupposes the assimilation not only of the plan of expression of a certain linguistic phenomenon, but also of the plan of its content, that is, the development in the students' minds of the concept of new objects and phenomena that have no analogues either in their native culture or in their native language. It is necessary for this to include elements of country studies in language teaching as this creates a synthetic type of teaching work called linguistic-and-country study teaching.

In order to teach a foreign language as a means of communication, it is necessary to create an environment of real communication, to establish a connection between teaching foreign languages and life, to actively use foreign languages in living, natural situations. It can be scientific discussions in the language with the involvement of foreign specialists and without it, abstracting and discussion of foreign scientific literature, reading individual courses in foreign languages, students' participation in international conferences, work as a translator, which is precisely about communication, contact, the ability to understand and convey information. It is necessary to develop extracurricular forms of communication: clubs, circles, open lectures in foreign languages, scientific societies of interest, where students of different specialties can gather.

The problem of intercultural communication in the study of foreign languages is that between teaching foreign languages and intercultural communication there is a single, complementary connection. The solution of this pragmatic problem is possible only on one condition that a fairly solid fundamental theoretical base would be created. To create it, it is necessary: 1) to apply the results of theoretical works in Philology to the practice of teaching foreign languages; 2) to theoretically comprehend and summarize foreign language teachers' vast practical experience [2]. With the traditional approach to the study of foreign languages, the main teaching methodology consisted of reading texts in a foreign language. And this concerned not only the school level of education, but also the higher, university level. The subject of everyday communication was represented by the same texts, only concerning the subjects of everyday communication, however, few of these specialists, having read such texts, could adequately behave in a real situation that would require the use of knowledge of a practical foreign language, but not its largescale literary side.

The very concept of intercultural communication is based on equal cultural interaction between representatives of various linguo-cultural communities, taking into account their originality, which leads to the need to identify common humanity on the basis of comparing foreign languages and their own cultures [8; 9]. Modern teaching of a foreign language is impossible without in- 
stilling in students a foreign language culture. Most methodologists focus on the current state of the theory and practice of teaching a foreign language with a pronounced communicative orientation, which contributes to the all-round development of the personality, the development of students' spiritual values. Intercultural communication training can't exist without including the linguistic-and-country study aspect in the learning process. In the light of modern requirements to learning goals, the status and role of country study information is changing, presented in such a way as to match students' experience, needs and interests and to be comparable with the similar experience of their peers in the country of the target language.

Traditionally, teaching foreign languages in our country was limited to reading texts. At the same time, at the level of higher education, the training consisted in the fact that philologists read fiction, but non-philologists read special texts according to their future profession, and everyday communication was considered a luxury or was represented by so-called everyday topics: at the hotel, at the restaurant, at the store. Studying of these famous topics in conditions of complete impossibility of real acquaintance with the world of the language under study and the practical use of the knowledge gained was useless.

Thus, almost exclusively one function of the language was realized, i.e. the function of the message, informative, and then in a narrowed form, since of the four skills of language proficiency (reading, speaking, writing, understanding), only one developed, focused on "recognition", i.e. reading.

Teaching foreign languages based only on written texts reduced the communicative capabilities of a language to a passive ability to understand texts created by someone, but not create, not generate speech, and without this, real communication is impossible.

In order to teach a foreign language as a means of communication, it is necessary to create an environment of real communication, to establish a connection between teaching foreign languages and life, to actively use a foreign language in living natural situations. The maximum development of communication skills is foreign language teachers' goal. Achieving the goal of teaching people to communicate, teaching people to speak a foreign language, but not only to understand foreign speech, is further complicated by the fact that communication is not just a verbal process. Its effectiveness depends on many factors: the conditions and culture of communication, the rules of etiquette, knowledge of non-verbal forms of expression and much more. Overcoming the language barrier is not enough to ensure effective communication between representatives of different cultures. To do this, you need to overcome the cultural barrier. An increase in the level of training of communicative communication, communication between people of different nationalities can be achieved only with understanding and taking into account the socio-cultural factor. One of the conditions for filling this gap is the expansion and deepening of the role of the socio-cultural component in the development of communication skills.

According to S.G. Ter-Minasova, "knowing the meanings and rules of grammar is clearly not enough to actively use the language as a means of communication. It is necessary to know as deeply as possible the world of the language being studied. In addition to the meanings and rules of grammar, you need to know: 1) when to say / write, how, to whom, with whom, where; 2) as a given meaning / concept, a given subject of thought lives in the reality of the studied language" [10]. Thus, mastering a foreign language code that allows successful intercultural interaction involves the study of cultural features that determine the specifics of a partner's social and business behavior, determined by the influence of historical traditions and customs, lifestyle, etc. Therefore, foreign languages as a means of communication between representatives of different peoples and cultures should be studied in inseparable unity with the world and culture of the peoples who speak these languages.

Conclusions. Summarizing the above mentioned, we can conclude that intercultural communication involves overcoming not only the language barrier, but also, very importantly, the cultural one. The formation of intercultural communication is an urgent task caused by global world processes. And it is language education that is called to fulfill this important mission. Educational activities should be aimed at a deeper holistic study of the culture of native speakers, their way of life, national character and mentality.

Further directions of research. These results can form the basis for the development of a model of successful training of future managers of socio-cultural activities in the field of intercultural communication. 


\section{References}

1. Grushevitskaya, T.G., Popkov, V.D., Sadokhin, A.P. (2002). Basics of Intercultural Communication. Moscow. 298 p.

2. Gudkov, D.B. (2003). Theory and Practice of Intercultural Communication. Moscow. 288 p.

3. Galitska, M.M. (2014). Intercultural communication and its significance for the professional activities of future professionals. Educational Discourse, 2(6), 23-32.

4. Mikhailichenko, Yu.V. (2016). International community as a dominant factor in the formation of the social community competence of the potential for the international community. Young Scientist, 4.1(31.1), $76-78$.

5. Georgieva, S. (2018) The polysubject interaction between the teacher and the student in the teaching of methodology - the path from the preferred to the realized and feasible. Interaction of teacher and student in the conditions of university education: traditions and innovations. Second book. Gabrovo, EX-PRESS. 350-355.

6. Batsevich, F.S. (2010). Essays on linguistic pragmatics: Monograph. Lviv: PAIS. $336 \mathrm{p}$

7. Vedenina, L.G. (2000). Theory of Intercultural Communication and the Meaning of the Word. Foreign Languages at School, 5, 72-76.

8. Kostenko, D.V. (2018). Intercultural communication in the modern world. Pedagogical education: theory and practice. Psychology. Pedagogy: collection of scientific works, 30, 80-85.

9. Slyushchinsky, B.V. (2004). Intercultural communication as a phenomenon of modern culture. New paradigm, 37, 223-232.

10. Ter-Minasova, S.G. (2000). Language and Intercultural Communication. Moscow. 624 p.

\section{Список бібліографічних посимань}

1. Грушевицкая Т.Г., Попков В.Д., Садохин А.П. Основы межкультурной коммуникации. М., 2002. 298 с.

2. Гудков Д.Б. Теория и практика межкультурной коммуникации. М., 2003. 288 с.

3. Галицька М.М. Міжкультурна комунікація та і1ї значення дмя професійної діяльності майбутніх фахівців. Освітологічний дискурс, 2014. № 2(6). C. 23-32.

4. Михайліченко Ю.В. Міжкультурна комунікація як домінуючий фактор формування іншомовної комунікативної компетенції майбутніх фахівців у гамузі міжнародних відносин. Молодий вчений, 2016. № 4.1(31.1). C. 76-78.

5. Георгиева С. Полисубектното взаимодействие между преподавателя и студента в обучението по методика - пътят от предпочитаното към осьщественото и осъществимото. Взаимодействие на преподавателя и студента в условията на университетското образование: традииии и иноващии. Втора книга. Габрово, ЕКС-ПРЕС, 2018. C. $350-355$.

6. Бацевич Ф.С. Нариси з мінгвістичної прагматики: Монографрія. $\Lambda$ ьвів: ПАІС, 2010. 336 с.

7. Веденина $\Lambda . Г$. Теория межкультурной коммуникации и значение слова. Иностранные языки в школе, 2000. № 5. C. 72-76.

8. Костенко Д.В. Міжкультурна комунікація у сучасному світі. Педагогічна освіта: теорія і практика. Психологія. Педагогіка: збірник наукових пращь, 2018. № 30. C. 80-85.

9. САющинський Б.В. Міжкультурна комунікація як феномен сучасної культури. Нова парадигма, 2004. Вип. 37. С. 223-232

10. Тер-Минасова С.Г. Язык и межкультурная коммуникация. М.: САово, 2000. 624 с.

ДАницюК Сергій Семенович,

доктор педагогічних наук, професор, завідувач кафедри педагогічних наук, освітнього і соціокумьтурного менеджменту,

Черкаський національний університет імені Богдана Хмельницького

\section{РОАЬ МІЖКУАЬТУРНОЇ КОМУНІКАЦІЇ У ПРОЦЕСІ ВИКААДАННЯ ІНОЗЕМНИХ МОВ МАЙБУТНIМ МЕНЕДЖЕРАМ СОЦІОКУАЬТУРНОӤ ДІЯАЬНОСТІ НА СУЧАСНОМУ ЕТАПІ}

Анотаиія. У статті йдеться про необхідність перегляду у проиесі викладання іноземних мов в Україні иілей, завдань і методів навчання у зв'язку зі стрімким входженням України у світове співтовариство, шо, у свою чергу, приводить до зміни як загальної методології, так $i$ конкретних методів, $i$ прийомів у теорії та практииі викладання іноземних мов.

Зазначається, шо основною метою навчання іноземної мови є формування мовної особистості, яка готова до реального, продуктивного спілкування з представниками інших культур на різних рівнях $і$ в різних сфрерах життя. На перший план при иьому виступає необхідність вербального забезпечення міжкультурної комунікаиії.

Закиентовано увагу на тому, шо наразі особливу важливість має інтегративний підхід до навчання іноземних мов в контексті діалогу культур, який передбачає, шо взаємодія різних картин світу, котрі подаються комунікантами, включае їх логіку, мислення, иіннісні смисли і не блокується, а стимулюється за допомогою взаєморозуміння, толерантності, позитивного ставлення.

Підкреслено той факт, ио відносини є міжкультурними якщо їх учасники не вдаються до власних традииій, звичаїв, уявлень $i$ способів поведінки, а знайомляться з чужими правилами і нормами по- всякденного спілкування. Для міжкультурної комунікаиії необхідна приналежність відправника $і$ одержувача повідомлення до різних культур. Для неї також необхідне усвідомлення учасниками комунікаиіі культурних відмінностей один одного. За своєю сутністю міжкультурна комунікаиія $є$ завжди між персональною комунікаиією у спеціальному контексті, коли один учасник виявляе культурну відмінність іншого.

Також йдеться про те, шо успішна міжкультурна комунікаиія передбачає, поряд із володінням іноземною мовою, ше й уміння адекватно інтерпретувати комунікативну поведінку представника іносоиіума, а також готовність учасників спілкування до сприйняття іншої форми комунікативної поведінки, розуміння ї̈ відмінностей $і$ варіювання від культури до культури. Стратегія зближення іншокультурних знань спрямована на запобігання не лише смислових, а й культурних збоїв у комунікаиї.

ключові слова: міжкультурне спілкування; викладання іноземних мов; менеджери соиіокультурної діяльності; мовна особистість; учасники спілкування; культурні відмінності; міжособистісне спілкування; комунікативна поведінка.

Одержано редакиією 01.11.2020 Прийнято до публікаиї 22.11.2020 